Danijel Mlinarić ${ }^{1}$, Ph. D.

\title{
KONCEPTUALNI OKVIR GOSPODARSKE DIPLOMACIJE
}

\section{CONCEPTUAL FRAMEWORK OF ECONOMIC DIPLOMACY}

Sažetak: Značaj gospodarske diplomacije u međunarodnim odnosima nedvojben je. Suradnja i komunikacija međunarodnih aktera nezaobilazno uključuje i gospodarsku diplomaciju, a ista posebno dolazi do izražaja s razvojem globalizacijskih procesa kada praktički postaje nezaobilazan faktor suvremenih gospodarskih odnosa. Iako pojam sam po sebi ne predstavlja kompleksnost razumijevanja, ipak postoji čitav niz tumačenja u dijelu značenja, uloge, instrumenata i determinanti gospodarske diplomacije. Najčešća je kolizija s pojmom komercijalne diplomacije, koja predstavlja uži pojam i podvrstu gospodarske diplomacije iako se ta dva termina često poistovjećuju. U 21. stoljeću gospodarska diplomacija predstavlja nazivnik svih diplomatskih aktivnosti ne isključujući nijedan tip institucija koje djeluju na međunarodnom planu. Stoga, kao i bilo koja druga poslovna aktivnost, gospodarska diplomacija ima za cilj maksimalni neto efekt djelovanja, što podrazumijeva maksimalnu razinu benefita uz najmanju razinu uloženih sredstava. Maksimizacija ciljeva obuhvaća ostvarivanje što većih razina izvoza, privlačenja direktnih stranih investicija te poticanje propulzivnosti i zaštite domaće ekonomije. Svakako različitost dimenzija gospodarske diplomacije, pritom misleći na bilateralnu, regionalnu i multilateralnu, doprinosi kompleksnosti definiranog problema područja. Navedeno uključuje i sve vrste institucija, od država kao esencijalnih dionika pa sve do multinacionalnih kompanija i nevladinih organizacija. Međutim, gospodarska diplomacija kao znanstveno područje ima čitav niz determinanti koje treba akceptirati kroz sve uključene institucije u proces provođenja politike gospodarske diplomacije. Kako bi se stvorile pretpostavke za navedeno potrebno je teorijski utvrditi i razlučiti znanstvenu definiranost gospodarske diplomacije, što ovaj rad ima za cilj.

KLJUČNE RIJEČI: gospodarska diplomacija, globalizacija, vanjska politika, ekonomska teorija

ABSTRACT: The importance of economic diplomacy is undoubted. Collaboration and communication between international actors involve economic diplomacy especially with the development of globalization when it becomes an unavoidable factor in contemporary economic relations. The term in its pure meaning doesn't have any misleading, still,

Danijel Mlinarić, Ph. D., Assistant Professor, Department of Economic Theory, Faculty of Economics and Business, University of Zagreb, Trg J. F. Kennedyja 6, HR-10000 Zagreb, Croatia, dmlinaric@efzg.hr 
there are different explanations in its defining, role, instruments, and determinants. Most often scholars misuse it with commercial diplomacy. It is a narrow term and presents one part of economic diplomacy. In the 21st Century, economic diplomacy is the denominator of all diplomatic activities which can not avoid even one institution in the international sphere. Like every other business activity, economic diplomacy is looking for a maximum of benefits with a minimum of costs. Goal maximization means the highest level of export, the highest level of foreign direct investment, and boosting of domestic economy efficiency. The diversity of dimensions of economic diplomacy like bilateral, regional, and multilateral contribute to the complexity of the remarked problem. However, economic diplomacy as a scientific field has many determinants that need to be accepted through the institutions which are involved in the process of implementation of economic diplomacy policy. A clear and undoubted theoretic definition with a scientific clearance of economic diplomacy is needed what this paper has for its goal.

KEYWORDS: economic diplomacy, globalization, foreign policy, economic theory

\section{UVOD}

U današnjem globaliziranom, informatiziranom i sveopće povezanom inozemnom okruženju, nijedna zemlja na svijetu, neovisno kako velika ili mala bila, ne smije zanemariti spomenute karakteristike. Navedeno posebice dolazi do izražaja na području gospodarstva zemalja jer je gospodarski rast primarni cilj svake zemlje kojim se ostvaruje veći životni standard stanovnika. S obzirom na navedene sveopće trendove koji obilježavaju 21. stoljeće zanemarivanje gospodarskih odnosa s drugim zemljama neminovno mora dovesti do negativnih ekonomskih konzekvenci za bilo koju zemlju. S obzirom na navedeno, adekvatno dijagnosticiranje i definiranje, pravilno vrednovanje, promoviranje i u konačnici implementacija adekvatnog modela gospodarske diplomacije nameće se kao conditio sine qua non opstojnosti bilo koje suvremene zemlje na svijetu. Da bi se mogao konstruirati adekvatan model gospodarske diplomacije, prije svega potrebno je nedvojbeno otkoniti sva razmimoilaženja unutar samog definicijskog okvira. Gospodarska diplomacija obuhvaća procese i postupke koji omogućavaju da zemlja ekonomski surađuje s ostatkom svijeta, pri tom maksimizirajući krajnji cilj uz minimizaciju troškova. Značaj gospodarske diplomacije nepobitan je za bilo koju zemlju na svijetu. Vidljiv je i prepoznat od strane nositelja ekonomske politike svake zemlje, a očituje se u formiranju posebnih državnih institucija, instituta, centara i odjela koji imaju zadatak prilagođavati strategiju i modele provođenja gospodarske diplomacije s obzirom na česte promjene u diplomatskom i ekonomskom okruženju. Primarni cilj i važnost gospodarske diplomacije nalazi se u njezinoj fokusiranosti na poboljšavanje ekonomskog položaja zemlje domaćina u odnosu prethodna razdoblja, ali i na strane zemlje. Dijelovi koje obuhvaća područje gospodarske diplomacije kvantitativno je vidljiv i praćen kroz kretanje vrijednosti izvoza, privlačenju direktnih stranih investicija i broju ugovorenih poslovnih aranžmana pri čemu gospodarska diplomacija stvara poslovne uvjete koji će potaknuti takav prosperitet. Poboljšanje navedenog će se postići teorijskim utvrđivanjem i razlučivanjem znanstvene utemeljenosti gospodarske diplomacije što upravo ovaj rad ima za cilj. Ovaj rad nakon uvoda obrađuje determinante razvoja gospodarske diplomacije u okviru koje se detaljno razlaže njen povijesni kontekst i globalizacija kao poticaj razvoju 
gospodarske diplomacije. U trećem poglavlju slijedi teorijsko-praktično poimanje gospodarske diplomacije koje obuhvaća pregled literature i definiciju gospodarske diplomacije te bibliografsku analizu. Četvrto poglavlje obrađuje pokazatelje koji se analiziraju u okviru mjerljivosti gospodarske diplomacije, a nakon kojeg slijede zaključna razmatranja.

\section{DETERMINANTE RAZVOJA GOSPODARSKE DIPLOMACIJE}

\subsection{Povijesni kontekst razvoja gospodarske diplomacije}

Nastanak gospodarske dipomacije nužno je promatrati kroz njeno semantičko značenje. U svojoj osnovi dolazi od dvije riječi: diplomacija i gospodarstvo. Diplomacija kao pojam jasan je i nedvojben. Začetke diplomatskih aktivnosti nalazimo još u vremenima prije Krista kroz poslove tadašnjih izaslanika. Međutim, suvremena diplomacija posljedica je postrenesansne ere na europskom tlu. Od tada diplomacija doživljava kontinuiranu evoluciju koja podrazumijeva sveobuhvatan napredak i utjecaj na svakodnevan život stanovnika država. Diplomacija koja se sastoji od pregovaranja, dijaloga i ostalih tehnika suradnje s drugim državama, a koje isključuju nasilno ponašanje te podrazumijeva utjecaj na donošenje odluka i stavove stranih država. U tom kontekstu potrebno je razmotriti i pojavljivanje samih gospodarskih odnosa između dviju država. Najjednostavniji oblici gospodarske diplomacije podrazumijevaju bilateralne odnose, tj. odnose između dviju država kojim se rješavaju gospodarska pitanja.

Prve pisane tragove bilateralne gospodarske diplomacije nalazimo još u davnoj prošlosti, točnije 1258. godina prije naše ere u Trgovinskom i mirovnom sporazumu između egipatskog faraona Ramzesa II. i babilonskog kralja Hatusila III. (1258. g. pr. n. e.) (Grimal, 1992). Činjenično možemo reći da primjese gospodarske diplomacije nalazimo još od vremena postojanja prve razmjene dobara i usluga. Svakako, moderna gospodarska diplomacija dominantno se počinje percipirati nakon završetka Drugog svjetskog rata u okviru razvoja međunarodnih ekonomskih odnosa (Rana, 2011). Međutim, tematika i usredotočenost na gospodarsku diplomaciju uvelike se razlikovala među državama. Neke države, poput Francuske oduvijek su naglašavale ekonomska pitanja u okviru diplomatskih aktivnosti. Još 1825. godine francusko Ministarstvo vanjskih poslova kreiralo je unutarnji odijel Ministarstva koji je djelovao po pitanju gospodarskih odnosa. Država je unatoč navedenom, dala dodatni impuls gospodarskoj diplomaciji i to iz dva razloga: prvi je razlog da bez ekonomskog i financijskog oporavka ne može postojati međunarodni utjecaj. I drugo, da će s ekonomskim oporavkom Francuska stvoriti pretpostavke sudjelovanja u gospodarskom rastu diljem svijeta pri čemu valja istaknuti činjenicu da se $90 \%$ toga rasta događa izvan Europe, a čak trećina u Kini (Sellal, 2014). Meksiko je pak, prve tragove gospodarske diplomacije imao još 1822 . godine s prvim službenim dokumentom vanjske politike izdanim od strane meksičke države (Caso, 2017). Belgija također gospodarsku diplomaciju postavlja kao najvažniju determinantu vanjske politike (Coolsaet, 2002). Općenito govoreći, istraživanje koje je provedeno 1998. godine govori da je većina ministara vanjskih poslova naglasila značaj i važnost gospodarske diplomacije za ukupnu vanjsku politiku država (Coolsaet, 1998). Aktivnosti gospodarske diplomacije u suvremenima društvima su nezaobilazne te ponekad i nevidljive na prvi dojam. U kontekstu 
navedenog, prema Kunzu, 1997., gospodarska diplomacija bila je ključ Sjedinjenih Američkih Država u pozitivnom rješavanju Hladnog rata u prošlom stoljeću. Time se gospodarska diplomacija prometnula u značajan faktor s obzirom na domaća vojna i ekonomska pitanja. U aktualnom tisućljeću skoro pa i ne postoji zemlja na svijetu koja ili ne diskutira ili je odredila nacionalnu strategiju razvoja gospodarske diplomacije. Jedna od njih je i Australija koja je 2014. godine proizvela i odobrila politiku gospodarske diplomacije s ciljem sveobuhvatnog pristupa ka poboljšanju trgovinskih odnosa i rasta investicija. U Ujedinjenom Kraljevstvu sve diplomatske misije imaju za prvotni cilj promovirati gospodarske interese u okviru gospodarske diplomacije. Primjeri Japana, Kine, Tajlanda i Brazila pokazuju da države imaju jasno obuhvaćene koncepte i teže ostvarivanju strategije gospodarske diplomacije (Grant Makokera, 2015). Općenito, konkretnije djelovanje i rasprostranjenost značaja gospodarske diplomacije započelo je pojavom globalizacije i srodnih popratnih promjena poput razvoja multinacionalnih kompanija.

Nedvojbeno gospodarska diplomacija dobiva na značaju s povećanom interakcijom među državnim ali i nedržavnim akterima na međunarodnom planu. Takve okolnosti omogućene su primarno napretkom ljudske civilizacije i to u informatičkom, komunikacijskom i prijevozničkom smislu. U 21. stoljeću pitanje prijenosa roba i usluga, a pogotovo podataka, ne predstavlja značajnu prepreku u ostvarivanju zadanih ciljeva i poslova. Navedeno omogućava kontakt i uspostavljanje poslovne suradnje diljem svijeta, neovisno o geografskom položaju. Sveopća digitalizacija, informatizacija uključujući i efikasna prijevozna sredstva poput avionskog prijevoza osiguravaju pristup tržištima proizvoda i usluga diljem svijeta. Takve okolnosti povećavaju konkurentnost te smanjuju cijenu proizvoda i usluga s obzirom na mogućnost specijalizacije i dostupnosti svih svjetskih tržišta (Mlinarić, 2020a). Svakako, obavljanje poslova izvan granica domicilnih država zahtijeva ispunjavanje mnoštva pretpostavki nužnih za uspješno poslovanje. Navedena okolnost jedna je od važnih značajki razvoja gospodarske diplomacije stoga se posljednjih dekada značajnije počela istraživati u stručnim i akademskim analizama. Upravo pitanje globalizacije zbog svoje važnosti je tematika koja se obrađuje u sljedećem potpoglavlju.

\subsection{Globalizacija kao poticaj razvoju gospodarske diplomacije}

Gospodarski napredak najvažniji je cilj svake države na svijetu. Države ga ostvaruju na temelju različitih modela i strategija, kako kratkoročnih tako i dugoročnih. Međutim, determinante koje određuju okolinu za postizanje spomenutog cilja sve su sličnije među zemljama neovisno o njenim okolnostima. Bilo da je riječ o maloj ili velikoj, bogatoj ili siromašnoj, demokratskoj ili autokratskoj, ili po bilo kojem drugom kriteriju (ne)usporedive države na svijetu imaju zajednički nazivnik u obliku sveprisutne i sverastuće globalizacije. Globalizacija je učinila svijet koji nas okružuje nikad isprepletenijim, kompleksnijim, povezanijim i kompetitivnijim (Mlinarić, 2020a). Postoji mnogo dimenzija globalizacije, ali najvažnije su ekonomska, politička, socijalna i kulturna. Ekonomska dimenzija globalizacije polazišna je točka mnoštva istraživanja u razmatranju fenomena globalizacije. Jedan od najznačajnijih doprinosa razvoju globalizacije je i Opći sporazum o carinama i trgovini (engl. General Agreement on Tariffs and Trade - GATT) (Motairi i Zaki, 2013). Opći sporazum o carinama i trgovini multilateralni je sporazum o carinskoj i vanjskotrgovinskoj politici, sa sjedištem u Ženevi. Sklopljen je 30. X. 1947. godine, a na snagu je stupio 1. I. 1948. godine, 
kada su ga ratificirale 23 zemlje. Najveću pozornost GATT posvećuje snižavanju carina pa je dosad organizirao nekoliko multilateralnih pregovora, od kojih su najznačajniji: tzv. Kennedyjev krug pregovora, koji je doveo do linearnoga snižavanja carina; Tokyjski krug pregovora, na kojem je dogovorena ekspanzija i veća liberalizacija svjetske trgovine progresivnim smanjivanjem trgovinskih zapreka te osiguranje dodatnih prednosti za zemlje $u$ razvoju uspostavljanjem sustava pravednijih cijena primarnih proizvoda i Urugvajski krug pregovora, kojem je jedan od ciljeva bio formiranje Svjetske trgovinske organizacije, koja je započela djelovati 1995. godine. Svjetska trgovinska organizacija (engl. World Trade Organization - WTO) u suradnji s Međunarodnim monetarnim fondom i Svjetskom bankom osigurava institucionalni okvir za djelovanje multilateralnoga sporazuma između zemalja članica (Hrvatska enciklopedija, 2020).

Upravo u razdoblju nakon Hladnog rata kada dominantno počinju djelovati ekonomski aspekti globalizacije i svjetske multipolarnosti, industrijalizirane zemlje postupno se preobražavaju u tržišno neoliberalne države. Pitanja međunarodne trgovine, kompetitivnosti i industrijsko-tehnološkog napretka postaju pitanja od primarnog interesa vladajućih elita. Strateška ulaganja u istraživanja i razvoj propagirana su od strane javnih agencija u OECD državama (Organizacija za ekonomsku suradnju i razvoj; engl. Organisation for Economic Co-operation and Development - OECD) kao pitanja od javnog interesa. Navedena pitanja, kao i pitanja necarinskih barijera (engl. Non-tariff barriers - NTBs) direktno su korelirana s djelovanjem gospodarske diplomacije (Unay, 2010). Važna komponenta globalizacije je i njena popraćenost tehnološkim napretkom. Leonidivna i Oleksiivna naglašavaju važnost i značaj uspješne međunarodne suradnje za tehnološko okruženje međunarodnog poslovanja, a koje određuje mogućnost efikasne suradnje poslovnih partnera u međunarodnom okruženju. Razina tehnologije jedna je od najvažnijih determinanti socijalne države i tržišta, a koja doprinosi podređenosti odnosno značaju zajedničkih ili odvojenih razvojnih puteva. Postoji čitav niz različitosti između egzistirajućih tržišta iz tehnološke perspektive, poput: mogućnost razvoja novih tehnologija, obuhvaćenost upotrebe tehnologije, razina uvoza i izvoza tehnologije i visokotehnoloških proizvoda, značajnost socio-ekonomskih promjena u društvu i organizaciji proizvodnje, a koje su sve posljedica tehnološkog razvoja (Leonidivna i Oleksiivna, 2015).

Iz samog razvoja industrije i društva iznjedrile su se i druge vrste diplomacije poput financijske ili NGO diplomacije. U svom radu, Lee i Hocking spominju i druge specifične vrste diplomacije poput katalitičke diplomacije, umrežavajuće diplomacije i diplomacije s mnoštvom sudionika (engl. catalytic diplomacy, network diplomacy, multi-stakeholder diplomacy) (Lee i Hocking, 2010). Takve promjene dovode do repozicioniranja društvenih institucija i kretanja, ali i promjena u poslovnim politikama i načelima. Svijest o navedenom nužna je za prilagodbu i uspješnu poslovnu egzistenciju, kako kratkoročnu tako i dugoročnu. Uska specijalizacija u gotovo svim djelatnostima kao i nova znanja te vještine potrebne za njeno svladavanje očituju se i u promjenama u okviru razvoja gospodarske diplomacije.

Gospodarska diplomacija u ovom stoljeću suočava se s čitavim nizom izazova koji proizlaze iz promjena u okviru globalne ekonomije, SAD - Kina odnosa, suprotstavljanju napretka globalizacije i ostalih izazova. Ulazak u novo stoljeće proizveo je multipolarnu svjetsku ekonomiju, u kojoj SAD više nije glavni pokretač ekonomskog rasta. Takav preokret dogodio se kao posljedica jačanja ekonomske snage Kine i ostalih azijskih zemalja u razvoju. Europska unija i dalje predstavlja najveći svjetski ekonomski blok, ali Azija kon- 
tinuirano doprinosi svjetskoj srednjoj ekonomskoj klasi sa stotinama milijuna novih pripadnika. Međutim, još uvijek su dva najvažnija motora globalnog ekonomskog rasta SAD i Kina. Tenzije koje se javljaju između tih dviju sila praktički predstavljaju povratak nadmetanja između Velikih sila (Yueh, 2020). Stoga, u godinama koje slijede, odnos SAD-a i Kine bit će važan za gospodarsku diplomaciju i globalno upravljanje (Levy, 2011). Sve navedene okolnosti doprinijele su i involviranju specijalnih državnih službi u analizu makroekonomske stabilnosti pojedine države, kako bi potencijalne prijetnje u budućnosti bilo moguće na vrijeme prevenirati. S obzirom na navedeno, jedna od zadaća specijalnih državnih agencija je i zaštita gospodarskog sustava pa je jedna takva agencija u Republici Hrvatskoj, Sigurnosno-obavještajna agencija - SOA uključena u prikupljanje i analizu podataka iz područja gospodarstva o temama koje mogu imati utjecaj na nacionalnu sigurnost i gospodarske interese Republike Hrvatske. Kao što je potvrdila Strategija nacionalne sigurnosti, gospodarska sigurnost važan je dio nacionalne sigurnosti jer utječe na suverenitet, zaštitu nacionalnih resursa i strateških sektora, kvalitetu života stanovništva te na političku i socijalnu stabilnost. Pri tome je osobito važna zaštita gospodarskog sustava u strateški važnim gospodarskim sektorima i kompanijama. Stoga je važno pratiti stanje s ciljem zaštite gospodarskih interesa. Takva institucija prati sigurnosne, gospodarske i financijske procese koji mogu utjecati na pozicioniranje hrvatskih gospodarskih subjekata u inozemstvu, kao i procese i aktivnosti koje bi mogle ugrožavati sigurnost gospodarskih subjekata, poglavito u nestabilnim područjima svijeta (SOA, 2020). U kontekstu prevladavajućih promjena na globalnoj razini može se reći da je ekonomska dimenzija međunarodnih odnosa determinirana prije svega globalizacijskim procesima. U takvim procesima u kojim je ultimativni cilj minimizacija troškova, a koji je izvjestan upravo zbog oskudnosti resursa s kojima se raspolaže nije netočno zaključiti neosporno važnu determinantu uspjeha u pogledu implementacije adekvatnog modela gospodarske diplomacije, uz jasan naglasak na ograničenja u provođenju politike gospodarske diplomacije. Jedno od važnijih je i adekvatno razumijevanje područja gospodarske diplomacije, a što sljedeća poglavlja imaju za cilj razlučiti.

\section{TEORIJSKO-PRAKTIČNO POIMANJE GOSPODARSKE DIPLOMACIJE}

\subsection{Pregled literature i definiranje gospodarske diplomacije}

Današnji diplomati imaju neprocjenjivu ulogu u svom svakodnevnom djelovanju na sam razvitak tržišnih kretanja neovisno jesu li uključeni u prodaju čarapa za državu ili sudjeluju u pregovaranju o kreditnom aranžmanu s Međunarodnim monetarnim fondom (Lee i Hocking, 2010). Takvim načinom i mogućnostima utjecaja, diplomati su postali neosporni predstavnici gospodarstava svojih zemalja i to na svim razinama poslovnih aktivnosti. Samo okruženje i raznovrsnost poslova diplomata kada je riječ o ekonomskoj dimenziji diplomacije posljedično i vrlo jasno utječe na definiciju i poimanje poslova u okviru gospodarske diplomacje. S obzirom na broj sudionika i geografski kriterij djelovanja gospodarske diplomacije istu možemo razlikovati u okviru bilateralne, regionalne, plurilateralne i multilateralne gospodarske diplomacije u kojoj su osnova gospodarski sporazumi.

Same razine djelovanja podrazumijevaju specifične aktivnosti u okviru modela gospodarske diplomacije. Prije svega potrebno je razlikovati gospodarsku diplomaciju (engl. 
economic diplomacy) i komercijalnu diplomaciju (engl. commercial diplomacy). Iako postoje autori koji smatraju da je riječ o sinonimu, dublja analiza dovodi ipak do ponešto drugačijeg zaključka. Komercijalna diplomacija smatra se podvrstom gospodarske diplomacije u okviru samog angažmana i obuhvata poslova koje komercijalna diplomacija obuhvaća. Pa se tako komercijalna diplomacija prema van Bergeijk i Moons (2018) ne može poistovjetiti s gospodarskom diplomacijom jer ona predstavlja dio gospodarske diplomacije kada se govori o dva sudionika u pregovorima u okviru privatnog sektora, a primarno se navedeno odnosi na promociju trgovine i privlačenja investicija. Van Bergeijk (2009) definira komercijalnu diplomaciju kao podkategoriju gospodarske diplomacije koja ima za cilj utjecati na donošenje odluka na međunarodnoj razini i to od strane nositelja vlasti i nedržavnog sektora. Obuhvaća pitanja izvoza, uvoza, investicija, financiranja, pomoći i migracija. Herbst (1969:323-324) je među prvima opisao diplomatske poslove koji pripadaju domeni gospodarstva, a koji pripadaju komercijalnoj diplomaciji te se sastoje od: promocije izvoza, povezivanja, umrežavanja poslovne zajednice i javnih institucija u stranoj zemlji, dojavljivanja informacija o trgovinskim sajmovima, javno objavljivanje podataka o poslovima države, izvještavanje o gospodarskom napretku te administrativnim preprekama koje utječu na bilateralnu trgovinsku razmjenu, omogućavanje olakšavanja provođenja trgovinskih sporazuma i multilateralnih trgovinskih politika, kao i izrada analiza za razvojnu pomoć. Položaj komercijalne diplomacije u odnosu na gospodarsku diplomaciju s multilateralne i bilateralne razine predočen je u sljedećem prikazu. Uključuje problematiku trgovinskih sporazuma (multilateralnih i bilateralnih), privlačenja investicija i trgovinsku promociju zajedno s umrežavanjem. Gospodarska diplomacija proširuje se za pitanja djelovanja u međunarodnim institucijama poput Svjetske banke i Međunarodnog monetarnog fonda, pribavljanje državnih pomoći, transferu tehnologije, brandinga te sudjelovanja u radu međunarodnih tijela poput komisija, vijeća i slično. Komercijalna diplomacija zapravo je podkategorija gospodarske diplomacije te njen sastavni i važan dio, ali ne i njegova istoznačnica.

Prikaz 1.: Odnos gospodarske i komercijalne diplomacije s karakteristikama

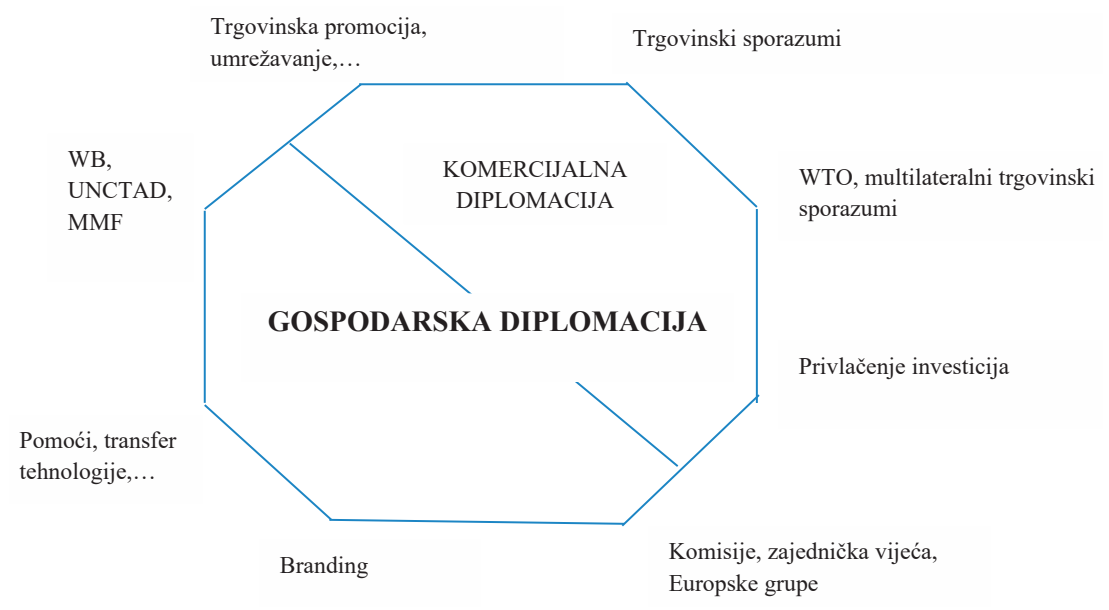

Izvor: priredio autor prema Rana, K. S. (2007). Economic diplomacy: the experience of Developing Countries, The New Economic Diplomacy, Decision-making and negotitation in international economic relations: editors Bayne, N. i Woolcock, Ashgate, drugo izdanje. 
Najzastupljenija područja djelovanja gospodarske diplomcije uključuju aktivnosti komercijalne diplomacije. Bellina (2019:38-39) u okviru svog doktorskog rada naveo je definicijski pregled osnovnih determinanti komercijalne odnosno u širem značenju gospodarske diplomacije prema izabranim značajnim autorima iz područja, a koji uključuju: a) promicanje izvoza (trgovinske razmjene) - Herbst, Berridge i James, Lee, Potter, Mercier, Naray, Van Bergeijk, Ozdem, Lee i Hocking, Van Bergeijk i ostali, Woolcock, Ruel i Visser, Feketekuty, Moons i de Boer; b) privlačenje investicija - Berridge i James, Lee, Mercier, Naray, Van Bergeijk, Ozdem, Lee i Hocking, Van Bergeijk i ostali, Potter, Ruel i Visser, Feketekuty, Moons i de Boer; c) zastupanje i promotivni poslovi - Naray, Lee i Hocking, Van Bergeijk i ostali, Kostecki i Naray, Okano-Heijmany, Verhagen i Bleker, Jiang, Ruel i Visser, Feketekuty i Ruel. Sve tri podkategorije predstavljaju okosnicu komercijalne diplomacije, a s obzirom da je komercijalna diplomacija potkategorija gospodarske diplomacije, onda ujedno i gospodarske diplomacije.

Gospodarska diplomacija predstavlja sredstvo vanjske gospodarske politike, a sudionici uključuju državne i nedržavne aktere. Državni akteri podrazumijevaju diplomate, državne službenike i zaposlenike i druge, dok nedržavni akteri podrazumijevaju transnacionalne kompanije, nevladine organizacije, trgovinske unije, lobistička poduzeća i ostale. Područje na kojem navedeni akteri sudjeluju je vrlo široko te uključuje domaću i međunarodnu ekonomiju (međunarodnu trgovinu, vanjsku trgovinu, financije i slično) te međunarodne organizacije (Ujedinjene narode, vladine i nevladine organizacije i slično) (Žirovčić, 2016a). Sama definicija gospodarske diplomacije uključuje pojam diplomacije koja prema Bull (1995) predstavlja upravljanje odnosa država s ostalim državama i drugim značajnim nedržavnim akterima uključenim u svjetsku politiku kroz svoje predstavnike. Ti predstavnici imaju za cilj mirnodopska rješenja kojima se želi povećati blagostanje sudionika, a koji se realiziraju kroz aktivnosti i procese na određenom geografskom području.

Mnoštvo determinanti koje određuju intenzitet i značaj gospodarske diplomacije predstavljaju i ograničenje njegove unisone definicije. Stoga postoji mnoštvo definicijskih određenja gospodarske diplomacije. Od općenitih poput Bayne i Woolcock, 2007 - koji gospodarsku diplomaciju usko povezuju s pitanjima donošenja odluka u međunarodno ekonomskom kontekstu. Do uže specificiranih poput japanskog primjera Japan Diplomatic Bluebook, 2019 - koji japansku gospodarsku diplomaciju sažima na tri područja: a) potpora donošenju regulatornog okvira slobodne trgovine na globalnoj razini i promicanje međunarodnih gospodarskih sporazuma; b) poticanje japanske ekspanzije na drugim kontinentima kroz javno-privatno partnerstvo; c) aktivno sudjelovanje diplomacije u privlačenju investicija. Općenito sljedeće definicije obuhvaćaju najčešći okvir gospodarske diplomacije pa se ističu definicije Okano-Heijmans, 2016 - gospodarska diplomacija uključuje aktivnosti u području trgovinske i investicijske promocije, trgovinskih pregovora, globalnih financija i razvojne pomoći; Bouyala Imbert, 2017 - gospodarska diplomacija temelji se na tri stupa i to: a) otvaranje stranih tržišta za domicilna poduzeća; b) privlačenje direktnih stranih investicija; c) zaštita i promoviranje nacionalnih interesa u okviru promjena i konstrukcija međunarodnih zakonodavnih okvira; Rana, 2007 - gospodarska diplomacija je proces kojim se države natječu s ostalim konkurentima na svjetskoj razini kako bi maksimizirali nacionalne ciljeve u području trgovine, investicija i ostalih oblika ekonomske razmjene u kojima domicilna država ima komparativnu prednost. Ona ima bilateralnu, regionalnu i multilateralnu dimenziju, od kojih je svaka od navedenih značajna za uspješnost gospodarske diplomacije. 
Gospodarska diplomacija obuhvaća korištenje svih državnih ekonomskih instrumenata za unapređivanje nacionalnih interesa u komunikaciji s ostalim državama. Predstavlja novu dimenziju vanjske politike u međupovezanom i isprepletenom svijetu. Strateške aktivnosti moraju uzeti u obzir pristup tržištima, telekomunikacije, energetsku infrastrukturu, financijske resurse i tarifne/netarifne barijere poslovanja. S međusobnim odnosom i kompleksnom prirodom svjetskih trgovinskih/financijskih mreža, aktivnosti koje jedna zemlja u odnosu na drugu poduzima, ne mogu se promatrati izolirano (Lorenz, 2015). Na primjeru Južne Afrike, Vickers i Ajulu (2008) opisuju gospodarsku diplomaciju kao politike i aktivnosti koji promoviraju trgovinu, direktne strane investicije, turizam i tehnološke transfere uz pozitivno pozicioniranje zemlje u svijetu kroz predstavljanje, brandiranje i javnu diplomaciju (domaću i stranu). Gospodarska diplomacija uključuje još i financijsku diplomaciju te konzularne i migracijske aktivnosti (Grant Makokera, 2015). S obzirom na spomenute činjenice i specifičnosti gospodarske diplomacije, osoba koja je zadužena provoditi politiku gospodarske diplomacije zemlje koju prezentira mora raspolagati specifičnim i temeljitim znanjima o području. Pa tako prema Žirovčiću (2016) gospodarski diplomat treba: biti upoznat s karakteristikama pojedinih sektora, uspostaviti mrežu kontakata, poznavati lokalna institucionalna pravila, privlačiti investicije, tražiti potencijalna mjesta ulaganja te promicati pozitivnu percepciju zemlje iz koje dolazi kao i njegove poslovne subjekte. Uz sve navedeno potrebno je i teorijski odabrati modele funkcioniranja i provođenja gospodarske diplomacije, a koji će biti najprimjereniji za odabranu državu. Prema Žirovčiću (2016) unificirani model jest model u kojemu Ministarstvo vanjskih poslova potpuno upravlja pitanjima povezanim s vanjskom trgovinom i vanjskim poslovima. Ključni akter takvog modela jest Ministarstvo vanjskih poslova. Isključivo Ministarstvo ima pravo pregovarati s trećim zemljama. Takav model gospodarske diplomacije primjenjuje Brazil. Brazil je jedna od rijetkih zemalja koju u WTO-u zastupa ministar vanjskih poslova. Djelomično unificirani model podrazumijeva model u kojemu Ministarstvo vanjskih poslova i Ministarstvo gospodarstva ili trgovine zajedno uspostavljaju posebni odjel koji se bavi trgovinom i investicijama. $\mathrm{U}$ tom modelu umjesto uobičajenih veleposlanika uvode se tzv. direktori - veleposlanici. Takav model egzistira u Tajlandu i Ujedinjenom Kraljevstvu. Model treće agencije jest model u kojem Ministarstvo vanjskih poslova nimalo nije nadležno za trgovinska pitanja. Neovisna tijela su ta koja se bave trgovinom, ali jednim dijelom su pod nadzorom Ministarstva. Primjer takvog modela nalazi se u Singapuru. Model natjecanja jest model u kojem se zadaci Ministarstava vanjskih poslova i drugih ministarstava preklapaju, bez jasne podjele poslova. Ovaj model rezultat je neusklađenosti ciljeva i aktivnosti. Model prepuštanja pak podrazumijeva da se ministar vanjskih poslova potpuno odriče pitanja vezanih za trgovinu i investicije te ih prepušta drugim ministarstvima. Ministarstva vanjskih poslova tada nemaju nikakvu ulogu u ekonomskim pitanjima za državu, a primjer takvog modela je Kina.

S obzirom na navedeno, može se reći da gospodarska diplomacija ima u fokusu minimalno tri osnovna područja na koja treba djelovati i to: privlačenje direktnih stranih investicija, povećanje izvoza te poboljšanje uvjeta poslovanja za domaće tvrtke u tuzemstvu i inozemstvu uz zaštitu nacionalnih interesa. Važno je napomenuti nužnost distinkcije i prilagodbe pojedinosti između razina djelovanja gospodarske diplomacije pritom misleći na unilateralnu, bilateralnu, regionalnu, plurilateralnu i multilateralnu gospodarsku diplomaciju (Mlinarić, 2020). Nedvojbeno je da gospodarska diplomacija predstavlja nezaobilazan faktor u ekonomskim aktivnostima bilo koje države na svijetu neovisno na koji način 
je definirana i koje institucije provode njenu politiku. Ograničavajući faktor predstavljaju budžeti kojima raspolažu institucije zadužene za provođenje gospodarske diplomacije, a koji nisu neograničeni pa je nužna optimizacija budžetskih aktivnosti. Stoga je ključno definirati kriterije i ciljeve koji će najbolje predstavljati stvarno stanje te povećati efikasnost gospodarske diplomacije, ali biti i kvantitativno egzaktni i točni (Mlinarić, Perić i Matejaš, 2019). Pritom je potrebno akceptirati i pozitivnu korelaciju osnivanja dodatnih diplomatskih predstavništava zemalja u stranim državama s najznačajnijim mjerljivim outputom gospodarske diplomacije (Mlinarić, Jošić i Thompson, 2020).

\section{2. Pregled mjerljivosti gospodarske diplomacije}

Svaki pojedini model gospodarske diplomacije je specifičan i nije moguće ,preslikati“ ga na neki drugi sustav. Uobičajeno je rezultat kombinacije dva već postojeća modela koji je prilagođen državi u koju se implementira. Takve okolnosti nisu neuobičajene s obzirom na nekonvencionalnost poslovnih modela koji postoje na svjetskoj razini. U okviru sklapanja ili dogovaranja poslova postoji čitav niz specifičnih determinanti koji su nužni za uspješno ostvarivanje i povećanje poslovnih aktivnosti i djelatnosti u okviru gospodarske diplomacije s naglaskom na dugoročnu stabilnost države (Mlinarić, 2020). Iako su modeli različiti, kvantitativni pokazatelji učinkovitosti gospodarske diplomacije su isti i mjerljivi. Dominantno su to izvoz i direktne strane investicije. Doprinos gospodarske diplomacije počiva i na veličini diplomatske mreže stoga se može i korelirati s brojem stranih misija u državama. Sljedeća tablica stoga daje pregled istih na svjetskoj razini.

Iz prethodne tablice može se zaključiti da po broju diplomatskih predstavništva u inozemstvu prednjače najrazvijenije države svijeta. Navedene države najvažnije su i prema ekonomskom, tj. gospodarskom utjecaju ali i političkom te međunarodnom utjecaju. Pozitivnu korelaciju dokazuju i Mlinarić, Jošić i Thompson, 2020. Kod makroekonomskih determinanti strani investitori analiziraju makroekonomsku stabilnost i rast nacionalne ekonomije. U kontekstu tih faktora ocjenjuje se stopa inflacije, udio državne potrošnje u BDP-u, proračunski suficit/deficit, saldo tekućeg računa platne bilance, vanjski dug, bruto međunarodne pričuve, stabilnost deviznog tečaja. Osim navedenih faktora svaki strani ulagač ovisno o motivu zbog kojeg pristupa tržištu analizira i ostale determinante poput: a) kod tržišno orijentiranih investicija analizira se ekonomska snaga tržišta kroz BDP i njegovu stopu rasta. Životni standard se procjenjuje putem BDP-a po glavi stanovnika i stope njegova rasta, ali i prosječnu nadnicu. Za veličinu tržišta važan je i broj stanovnika u nekoj zemlji, b) kod resursno orijentiranih investicija važna je raspoloživost i kvaliteta resursa, a time i njihova cijena pa se kod procjene ove determinante razmatra kvaliteta tržišta rada kroz stopu nezaposlenosti, prosječnu plaću ili jedinični trošak rada, kvalitetu ljudskog kapitala. Razvijenost tržišta kapitala je važna, kao i sama cijena koja se procjenjuje kroz kamatnu stopu, dok je zemlja relevantan faktor u manjem broju djelatnosti. Kod investicija u turizam sigurno je važna prirodna ljepota obale, njena razvedenost, otoci, čistoća mora itd., c) investicije vođene efikasnošću podrazumijevaju ostvarivanje veće efikasnosti u stranoj zemlji u odnosu na domaću pa je tu važna razvijenost infrastrukture koja se može pratiti kilometrima izgrađenih autocesta, brojem luka, kvalitetom pravnog okvira i pravosudnog sustava, razvijenost institucija itd. Investitore procjenjuju i trošak električne energije, porezno opterećenje financijskog rezultata, porezno opterećenje rada itd. (Škuflić, Mlinarić i 
Tablica 1.: Pregled stranih misija prema državama u 2019. godini

\begin{tabular}{|c|c|c|c|c|c|}
\hline DRŽAVA & UKUPNO & $\begin{array}{l}\text { AMBASA- } \\
\text { DE }\end{array}$ & $\begin{array}{l}\text { KONZU- } \\
\text { LATI }\end{array}$ & \begin{tabular}{|l} 
TRAJNE \\
MISIJE
\end{tabular} & \begin{tabular}{|c} 
OSTALA \\
PREDSTAVNIŠTVA
\end{tabular} \\
\hline Kina & 276 & 169 & 96 & 8 & 3 \\
\hline SAD & 273 & 168 & 88 & 9 & 8 \\
\hline Francuska & 267 & 161 & 89 & 15 & 2 \\
\hline Japan & 247 & 151 & 65 & 10 & 21 \\
\hline Rusija & 242 & 144 & 85 & 11 & 2 \\
\hline Turska & 235 & 140 & 81 & 12 & 2 \\
\hline Njemačka & 224 & 150 & 61 & 11 & 2 \\
\hline Brazil & 222 & 138 & 70 & 12 & 2 \\
\hline Španjolska & 215 & 115 & 89 & 10 & 1 \\
\hline Italija & 209 & 124 & 77 & 8 & 0 \\
\hline UK & 208 & 152 & 44 & 9 & 3 \\
\hline Indija & 186 & 123 & 54 & 5 & 4 \\
\hline Južna Koreja & 183 & 114 & 51 & 5 & 13 \\
\hline Argentina & 157 & 86 & 62 & 7 & 2 \\
\hline Meksiko & 157 & 80 & 67 & 7 & 3 \\
\hline Nizozemska & 152 & 107 & 29 & 12 & 4 \\
\hline Švicarska & 146 & 103 & 30 & 10 & 3 \\
\hline Kanada & 144 & 96 & 36 & 10 & 2 \\
\hline Poljska & 136 & 88 & 36 & 9 & 3 \\
\hline Grčka & 135 & 82 & 43 & 9 & 1 \\
\hline Indonezija & 132 & 94 & 34 & 3 & 1 \\
\hline Mađarska & 131 & 86 & 35 & 7 & 3 \\
\hline Čile & 128 & 70 & 51 & 6 & 1 \\
\hline Portugal & 128 & 71 & 48 & 8 & 1 \\
\hline Južna Afrika & 124 & 106 & 14 & 2 & 2 \\
\hline Australija & 118 & 81 & 31 & 4 & 2 \\
\hline Belgija & 118 & 82 & 22 & 9 & 5 \\
\hline Pakistan & 117 & 85 & 30 & 2 & 0 \\
\hline Češka & 116 & 90 & 19 & 5 & 2 \\
\hline S. Arabija & 114 & 96 & 15 & 2 & 1 \\
\hline Malezija & 107 & 80 & 23 & 3 & 1 \\
\hline Tajvan* & 107 & 15 & 2 & 1 & 89 \\
\hline Izrael & 104 & 77 & 20 & 6 & 1 \\
\hline Švedska & 104 & 88 & 8 & 7 & 1 \\
\hline Norveška & 99 & 79 & 9 & 10 & 1 \\
\hline
\end{tabular}




\begin{tabular}{|c|c|c|c|c|c|}
\hline DRŽAVA & UKUPNO & $\begin{array}{l}\text { AMBASA- } \\
\text { DE }\end{array}$ & $\begin{array}{l}\text { KONZU- } \\
\text { LATI }\end{array}$ & $\begin{array}{l}\text { TRAJNE } \\
\text { MISIJE }\end{array}$ & $\begin{array}{c}\text { OSTALA } \\
\text { PREDSTAVNIŠTVA }\end{array}$ \\
\hline Austrija & 98 & 80 & 9 & 7 & 2 \\
\hline Tajland & 98 & 65 & 29 & 3 & 1 \\
\hline Vijetnam & 96 & 69 & 22 & 4 & 1 \\
\hline Danska & 89 & 67 & 14 & 6 & 2 \\
\hline Irska & 87 & 66 & 14 & 6 & 1 \\
\hline Filipini & 87 & 60 & 23 & 4 & 0 \\
\hline Finska & 85 & 70 & 6 & 6 & 3 \\
\hline \begin{tabular}{|l|} 
Slovačka \\
\end{tabular} & 81 & 63 & 8 & 8 & 2 \\
\hline Bangladeš & 75 & 57 & 16 & 2 & 0 \\
\hline Novi Zeland & 72 & 50 & 17 & 4 & 1 \\
\hline Šri Lanka & 67 & 51 & 13 & 2 & 1 \\
\hline Litva & 61 & 40 & 12 & 8 & 1 \\
\hline \begin{tabular}{|l|} 
Slovenija \\
\end{tabular} & 54 & 41 & 5 & 7 & 1 \\
\hline \begin{tabular}{|l|} 
Južna Koreja \\
\end{tabular} & 52 & 47 & 3 & 2 & 0 \\
\hline \begin{tabular}{|l|} 
Singapur \\
\end{tabular} & 50 & 28 & 17 & 4 & 1 \\
\hline Latvija & 47 & 37 & 3 & 7 & 0 \\
\hline Estonija & 44 & 36 & 2 & 6 & 0 \\
\hline Mianmar & 44 & 36 & 6 & 2 & 0 \\
\hline Mongolija & 43 & 30 & 11 & 1 & 1 \\
\hline Bruneji & 42 & 35 & 4 & 3 & 0 \\
\hline Laos & 39 & 26 & 10 & 3 & 0 \\
\hline Nepal & 39 & 32 & 6 & 1 & 0 \\
\hline Kambodža & 38 & 25 & 10 & 3 & 0 \\
\hline Luksemburg & 37 & 26 & 7 & 3 & 1 \\
\hline \begin{tabular}{|l|} 
Island \\
\end{tabular} & 25 & 16 & 4 & 5 & 0 \\
\hline Butan & 9 & 5 & 2 & 2 & 0 \\
\hline
\end{tabular}

Izvor: prema Lowy Institute, 2020.

Mišević, 2016). Sve navedene karakteristike moraju biti akceptirane u okviru razumijevanja i konstruiranja modela gospodarske diplomacije. Pa tako možemo navesti da su unutar mikroekonomskih determinanti važni oni čimbenici koji su relevantni za pojedinu investiciju. Tako se kod investicija u turizam promatra kretanje potencijalne turističke potražnje, ali i raspoloživost domaće radne snage, njena kvaliteta i stupanj obrazovanja. Kod investicija u naftnu industriju važno je procijeniti raspoložive izvore nafte, eksploataciju. No u svim pojedinačnim prilikama investitori ocjenjuju kakav je „,poduzetnički duh“ u zemlji, kakva je konkurencija unutar same djelatnosti i između djelatnosti, postojanje klastera, kakva je uloga sindikata, fleksibilnost tržišta rada, kakva je produktivnost pojedinih faktora proizvodnje unutar djelatnosti u koju se želi investirati u odnosu na produktivnost u domaćoj 
zemlji, stupanj tehnologije te kakva je profitabilnost djelatnosti u cjelini. Za strane ulagače važan je udio privatnog sektora u nekoj državi, kao i kvaliteta procesa privatizacije posebice kada je riječ o tranzicijskim ekonomijama (Škuflić, Mlinarić i Mišević, 2016). Spomenuto je važno u okviru trećeg stupa aktivnosti gospodarske diplomacije, a to je osiguravanje poslovnih mogućnosti i podizanje kvalitete poslovanja za domaća poduzeća u tuzemstvu i inozemstvu, pritom uvažavajući sve tržišne principe i zakonitosti, ali i nacionalne interese.

\section{BIBLIOGRAFSKA ANALIZA}

Ekonomske dimenzije diplomatske prakse još uvijek ne privlače puno pažnje, međutim sve više postoji svijest da je gospodarska diplomacija izrazito značajna za razumijevanje ali i sam koncept diplomacije generalno (Lee i Hocking, 2010). Reuvers i Ruel (2012) koji su analizirali postojeću literaturu te zaključili da se broj znanstvenih istraživanja značajno povećao u odnosu na 1990. godine. Prema Mlinarić (2018) u promatranom razdoblju od 1961. godine do veljače 2018. godine u prosjeku broj znanstvenih članaka objavljenih u relevantnoj bazi znanstvenih članaka Thompson Reuters Web of Science Core Collection, najveći je nakon 2010. godine. Podaci objavljeni u radu van Bergeijk i Moons (2018) također govore o značajnom povećanju znanstvenih istraživanja povezanih s gospodarskom diplomacijom. Njihovo istraživanje obuhvaća znanstvena istraživanja povezana s gospodarskom diplomacijom od 1950. godine do 2016. godine. Jasno je vidljivo povećanje broja istraživanja u 21. stoljeću, a posebice nakon 2010. godine. Sljedeći grafikon stoga pokazuje pregled broja radova objavljenih u relevantnim bazama.

Grafikon 1.: Pregled broja radova od 1955. do 2019. godine objavljenih u znanstvenim bazama SCIEXPANDED, SSCI, A\&HCI, CPCI-S, CPCI-SSH, BKCI-S, BKCI-SSH, ESCI, CCR-EXPANDED, IC koji sadrže „economic diploma“ u naslovu rada

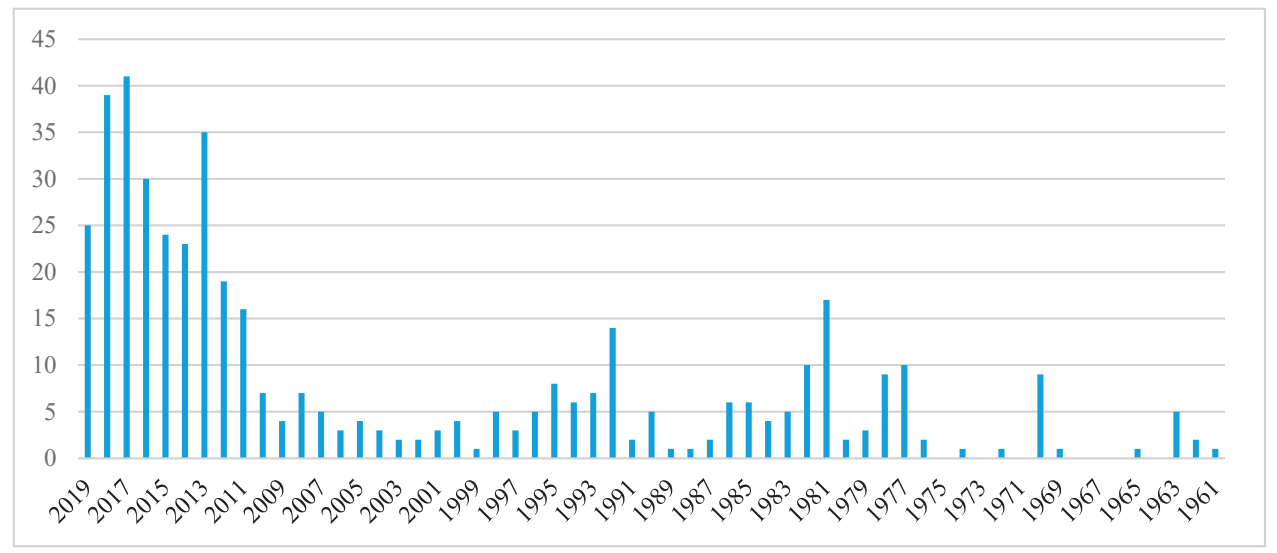

Izvor: priredio autor, 2020. godina.

Prethodni grafikon pokazuje pregled broja radova od 1955. do 2019. godine objavljenih u znanstvenim bazama SCI-EXPANDED, SSCI, A\&HCI, CPCI-S, CPCI-SSH, BKCI-S, BKCI-SSH, ESCI, CCR-EXPANDED, IC koji sadrže „economic diploma“ u naslovu rada. Vidljivo je značajno povećanje broja radova nakon 2010. godine, što je u skladu s pro- 
vedenim istraživanjima o zastupljenosti područja gospodarske diplomacije u znanstvenim radovima. Najveći broj radova objavljen je 2017. godine i to 41. Ukupno u promatranom razdoblju objavljen je 451 rad koji je eksplicite u naslovu rada imao sintagmu „economic diploma“, s ukupno 1908 citata i h-indexom 18. Distribucija potvrđuje kontinuiranu zastupljenost područja gospodarske diplomacije u znanosti. Kako bi se dobio konkretniji uvid u distribuciju provedenih istraživanja sljedeći grafikon pokazuje razvrstavanje radova prema citatnim indeksima.

Grafikon 2.: Pregled broja radova od 1955. do 2019. godine objavljenih u znanstvenim bazama SCIEXPANDED, SSCI, A\&HCI, CPCI-S, CPCI-SSH, BKCI-S, BKCI-SSH, ESCI, CCR-EXPANDED, IC koji sadrže „economic diploma“ razvrstanih prema citatnim indeksima

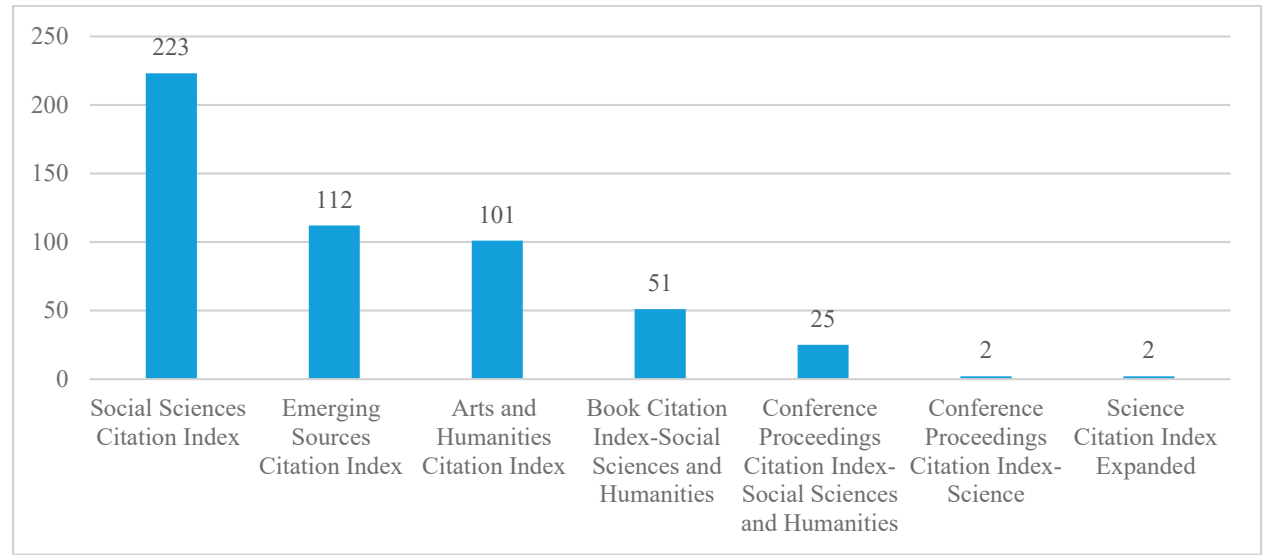

Izvor: priredio autor, 2020. godina.

Najveći broj objavljenih radova prema navedenom kriteriju je u okviru indeksa društvenih znanosti, čak 223 objavljena rada u promatranom periodu od 1955. do 2019. godine. Nakon toga slijedi indeks iz područja ekonomija u nastajanju. Sve navedeno u korelaciji je sa svime prethodno navedenim pa sljedeći grafikon prikazuje broj radova u istom razdoblju,

Grafikon 3.: Pregled broja radova od 1955. do 2019. godine u znanstvenim bazama SCI-EXPANDED, SSCI, A\&HCI, CPCI-S, CPCI-SSH, BKCI-S, BKCI-SSH, ESCI, CCR-EXPANDED, IC koji sadrže „economic diploma" u naslovu rada, a razvrstani su prema vrsti znanstvenog objavljivanja

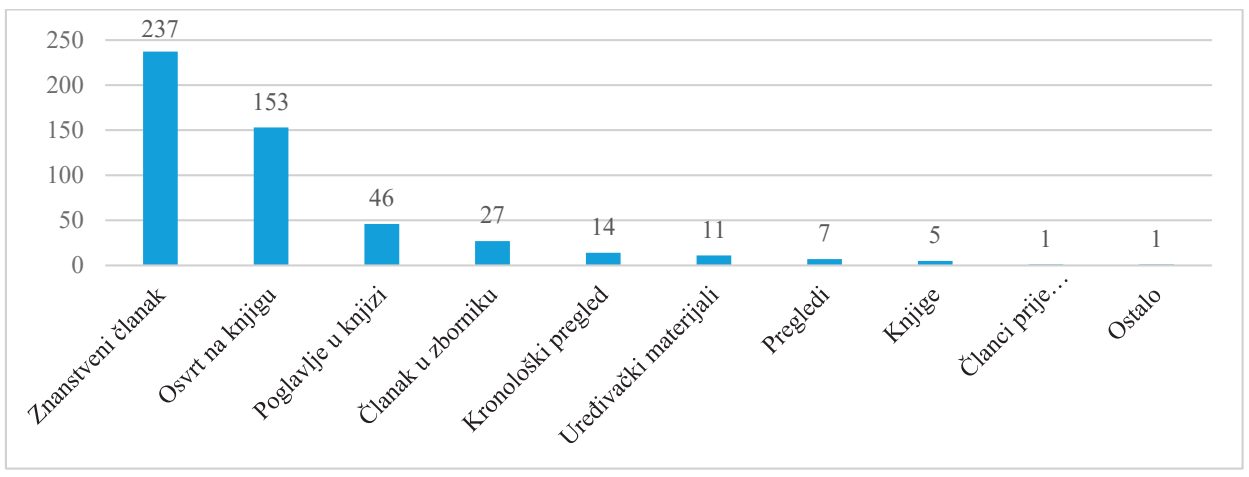

Izvor: priredio autor, 2020. godina. 
ali s aspekta vrste znanstvenog objavljivanja. Najveći broj objavljen je u okviru znanstvenih članaka i to 237 njih, slijedi 153 osvrta, 46 poglavlja u knjizi i 27 članaka objavljenih u zbornicima sa znanstvenih konferencija. Na temelju analiziranoga zaključuje se da je područje gospodarske diplomacije novo, međutim i znanstveno područje s izrazitom potrebom većeg broja istraživanja, što i potvrđuje znatan rast broja objavljenih znanstvenih radova u relevantnim znanstvenim bazama.

Kako bi se dobila geografska distribucija zemalja iz kojih dolaze autori objavljenih radova sljedeći grafikon pokazuje upravo navedeno. Najveći broj radova iz područja gospodarske diplomacije odnosno radova koji u naslovu spominju sintagmu ,economic diploma“ dolazi iz Sjedinjenih Američkih Država sa 103 rada, slijedi 58 radova iz Ujedinjenog Kraljevstva, 27 iz Nizozemske, 16 iz Kine, Kanade i Australije, 13 iz Rusije te 12 iz Belgije i Švicarske.

Grafikon 4.: Pregled broja radova od 1955. do 2019. godine objavljenih u znanstvenim bazama SCIEXPANDED, SSCI, A\&HCI, CPCI-S, CPCI-SSH, BKCI-S, BKCI-SSH, ESCI, CCR-EXPANDED, IC koji sadrže ,economic diploma“ u naslovu rada prema nacionalnosti autora rada

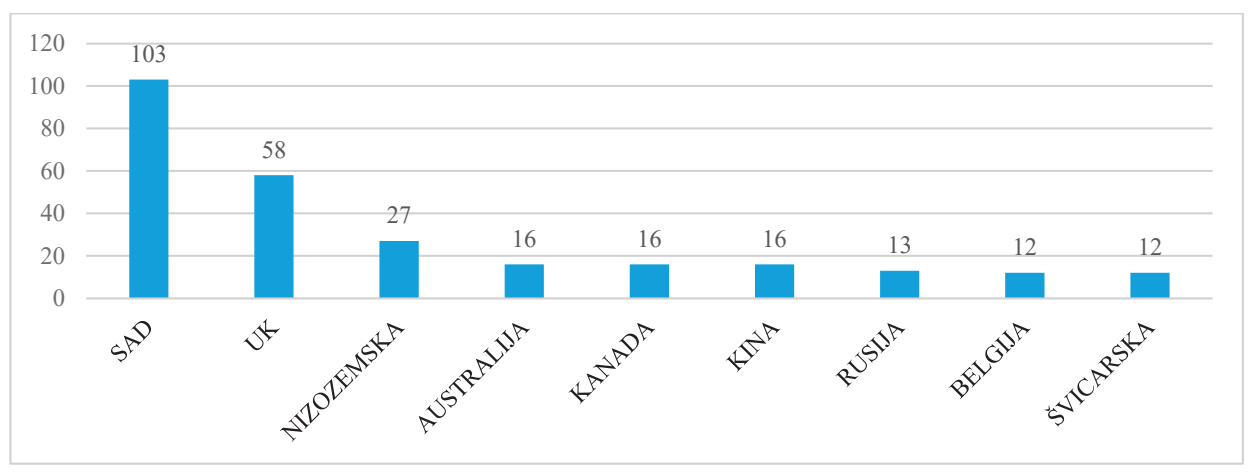

Izvor: priredio autor, 2020. godina.

\section{ZAKLJUČAK}

Područje gospodarske diplomacije u literaturi je relativno novo, značajnije se znanstveno počinje istraživati kao područje tek posljednjih desetljeća. Svakako da se djelovanja u okviru gospodarske diplomacije spominju i prije, ali u okviru drugačijih konceptualnih okvira. Može se zapravo reći da gospodarska diplomacija postoji još od najranijih vremena s početcima trgovinskih odnosa u svijetu. Kompleksnost samog područja gospodarske diplomacije očituje se već u njenom samom imenu koji objedinjuje pitanja gospodarstva i diplomacije. Područja su to koja zasebno iziskuju specijalna znanja i vještine, a posebno kada ih se dovede u korelaciju. Stoga je važno temeljito, kvalitetno i sveobuhvatno pristupiti problematici gospodarske diplomacije uključujući sve prednosti i nedostatke ovog specifičnog i nadasve važnog znanstvenog područja. Svi definirani strateški ciljevi država moraju biti usklađeni s politikom gospodarske diplomacije koja treba pružiti simultanu, kratkoročnu i dugoročnu potporu definiranim ciljevima. To može isključivo u trenutku kada su za to ispunjeni preduvjeti koji su nužni za efikasnu politiku gospodarske diplomacije, a oni uključuju 
usredotočenost na tri osnovno mjerljiva fokusa gospodarske diplomacije: a) direktne strane investicije; b) izvoz i c) potporu poduzećima na domaćem i međunarodnim tržištima uz uvažavanje svih nacionalnih strateških interesa. Pri svemu navedenom potrebno je istaknuti da je model gospodarske diplomacije određen specifičnim internim i eksternim okolnostima koji se ne mogu zaobići na način implementacije već postojećeg modela gospodarske diplomacije koji već na nekom primjeru egzistira. Stoga je sveobuhvatna analiza temeljena na znanstvenim i stručnim analizama eksperata iz područja gospodarske diplomacije kao i praktičara nužna kako bi se postojeći modeli gospodarske diplomacije prilagodili unaprijed postavljenim strateškim ciljevima.

Konačno, može se reći da je gospodarska diplomacija nezaobilazno područje interesa u okviru napretka bilo koje države na svijetu. Osnovni ciljevi gospodarske diplomacije uključuju privlačenje direktnih stranih investicija, povećanje izvoza te poboljšanje poslovnog okruženja poduzeća u tuzemstvu i inozemstvu uz uvjet zaštite strateških nacionalnih interesa.

\section{POPIS LITERATURE}

1. Al Motairi, N. R. T. i Zaki, A. R. (2013). Globalisation and Its Impact on Economic Diplomacy - An Empirical Study of Kuwait. IOSR Journal of Business and Management (IOSR-JBM). Volume 15, Issue 1, str. 54.-59.

2. Bayne, N. i Woolcock, S. (2007). The New Economic Diplomacy, Decision-making and negotitation in international economic relations: editors Bayne, N. i Woolcock, S., Routledge, Global Governance, London i New York.

3. Bellina, Ž. (2019). Commercial diplomacy as an instrument for enhancing national economy internationalisation: the case of the Republic of Serbia, University of Ljubljana, doktorski rad.

4. Bouyala Imbert, F. (2017). EU economic diplomacy strategy, Policy Department, Directorate-General for External Policies, EU.

5. Bull, H. (1995). The Anarchial Society: A Study of Order in World Politics, Drugo izdanje Foreign Policy Analysis, 4, London.

6. Caso, L. V. (2017). Mexico's Economic Diplomacy: Precedents, Strategies and Perspectives, Comercio Exterior Bancomext (Pristupano 28. 9. 2020. https://www.revistacomercioexterior.com/articulo.php?id=313\&t=mexicos-economic-diplomacy-precedents-strategies-and-perspectives).

7. Coolsaet, R. (1998). The transformation of diplomacy at the threshold of the new millennium. Leicester, University of Leicester, Centre for the Study of Diplomacy, DSP Discussion Papers, nr. 48, str. 27.

8. Coolsaet, R. (2002). Historical Patterns in Economic Diplomacy. From Protectionism to Globalisation. The case of Belgium.

9. Grant Makokera, C. (2015). South African Economic Diplomacy: Engaging the private sector and parastatals, Institute for Security Studies, ISS Paper 280.

10. Grimal, N. (1992). A History of Ancient Egipt, Blackwell, Oxford. 
11. Herbst, A. (1969). The commercial counsellor's field of activity, Intereconomics, ISSN 0020-5346, Verlag Weltarchiv, Hamburg, Vol. 04, Iss. 10, str. 323-325.

12. Jošić, H. i Mlinarić, D. (2018). Determinants of Sovereign Credit Ratings: Evidence from CEE Countries, EconViews, Year XXXI, Number 2, str. 319.-335.

13. Kunz B. D. (1997). Butter and Guns: Americas Cold War Economic Diplomacy. New York: FreePress.

14. Lee, D. i Hocking, B. (2010). Economic Diplomacy u Robert A. Denemark (ed.) The International Studies Encyclopedia, Vol. II, str. 1216-1227. Wiley Blackwell.

15. Leonidivna, K. O., Oleksiivna, M. O. (2015). Global Trends of Economic Diplomacy Development under Globalization. Journal Marketing and Management of Innovations. ISSN 2227-6718.

16. Levy, P. (2011). The United States and the PRC: Macroeconomic Imbalances and Economic Diplomacy, ADBI Working Paper Series, Broj 328.

17. Lorenz, L. (2015). Principles in Action: Economic Diplomacy as the New Face of American Global Leadership. White Paper. American Security Project.

18. Ministarstvo vanjskih poslova Japana (2019). Diplomatic Bluebook, MFA.

19. Mlinarić, D. (2018). Theoretical Background of Economic Diplomacy, International Conference Proceedings BSSHE-18 ISBN 978-93-84422-81-3, str. 22.-28.

20. Mlinarić, D. (2020a). Komparativna analiza sustava gospodarske diplomacije Republike Hrvatske i Republike Singapur, završni rad, Ministarstvo vanjskih i europskih poslova RH.

21. Mlinarić, D., Jošić, H. i Thompson, C. (2020). Investigating The Effect of Diplomatic Representation on Trade: A Case Study Of Croatia, IGI Global Book, Bridging Microeconomics and Macroeconomics and the Effects on Economic Development and Growth: editor Kostis, P.

22. Mlinarić, D., Perić, T. i Matejaš, J. (2019). Multi-objective programming methodology for solving economic diplomacy resource allocation problem, Croatian Operational Research Review CRORR 10, Vol. 10, No. 1, str. 165-174.

23. Okano-Heijmans, M. (2016). Economic Diplomacy, Handbook of Diplomacy: editors Constantinou, C., Sharp, P. i Kerr, P., The SAGE, London.

24. Opći sporazum o carinama i trgovini (2020). Hrvatska enciklopedija, mrežno izdanje. Leksikografski zavod Miroslav Krleža, (Pristupljeno 1. 10. 2020. http://www.enciklopedija.hr/Natuknica.aspx?ID=45222).

25. Rana, K. S. (2007). Economic diplomacy: the experience of Developing Countries, The New Economic Diplomacy, Decision-making and negotitation in international economic relations: editors Bayne, N. i Woolcock, Ashgate, drugo izdanje, str. 201-220.

26. Rana, K. S. (2011). Serving the Private Sector: India's Experience in Context. In The New Economic Diplomacy: Decision-Making and Negotiation in International Economic Relations; 3rd edition, eds. Nicholas Bayne and Stephen Woolcock, 93-113: Farnham: Ashgate Publishing, Ltd.

27. Reuvers, S. i Ruel, H. J. M. (2012). Research on Commercial Diplomacy: a review and implications, Commercial Diplomacy and International Business: a conceptual 
and empirical exploration. Advanced Series in Management, Emerald Publishers Ltd., ISBN 9781780526744, str. 1-27.

28. Sellal, P. (2014). Economic Diplomacy. Govor na Generalnom sastanku CCI France. Ministere de L'Europe et des Affaires Etrangeres.

29. Sigurnosno-obaviještajna agencija (2020). SOA-gospodarska sigurnost. (Pristupano 28. 09. 2020. www.soa.hr).

30. Sisek, B. (2005). Strane izravne investicije u Hrvatskoj - uzroci neuspjeha, Zbornik Ekonomskog fakulteta u Zagrebu. godina 3, Zagreb.

31. Škuflić, L., Mlinarić, D. i Mišević, P. (2016). Political risk governance for FDI progress, Second International Scientific-Business Conference LIMEN, str. 18-34.

32. Turk, Zagreb.

33. Unay, S. (2010). Economic Diplomacy for Competitiveness: Globalization and Turkey's New Foreign Policy, Perceptions, Volume XV, Number 3-4, str. 21-47.

34. van Bergeijk, P. A. G. i Moons, J. V. S. (2018). Introduction to the Research Handbook on Economic Diplomacy, Research Handbook on Economic Diplomacy - Bilateral Relations in a Context of Geopolitical Change: editors A. G. van Bergeijk i J. V. Moons, Edward Elgar Publishing, UK.

35. van Bergeijk, P. A.G. (2009). Economic Diplomacy and the Geography of International Trade. Cheltenham: Edward Elgar Publishing Limited.

36. Vickers, B. i Ajulu, R. (2008). South Africa's Economic Diplomacy: Trade and Investment Promotion, report prepared for the Presidency's Fifteen Year Review by the Institute for Global Dialogue, Pretoria, March 2008, 5.

37. Yueh, L. (2020). Economic Diplomacy in the 21st Century: Principles and Challenges. LSE IDEAS Strategic Update.

38. Žirovčić, D. (2016). Gospodarska diplomacija: Izabrani nacionalni modeli, Jesenski i Turk, Zagreb.

39. Žirovčić, D. (2016a). Theoretical Principles of Economic Diplomacy, SSRN (Pristupano 10. 9. 2020. https://papers.ssrn.com/sol3/papers.cfm?abstract_id=2710671). 